\title{
Project management in the development of a command-information system for the needs of defence systems of small states
}

\author{
Zoran Karavidić \\ Department of Management University \\ of Defence in Belgrade \\ Belgrade, Serbia \\ zoran.karavidic@va.mod.gov.rs
}

\author{
Goran Radovanović \\ Rectorate \\ University of Defence in Belgrade \\ Belgrade, Serbia \\ goran.radovanovic@vs.rs
}

\author{
Vladimir Ristić \\ Rectorate \\ University of Defence in Belgrade \\ Belgrade, Serbia \\ vladimir.ristic@mod.gov.rs
}

\begin{abstract}
This paper discusses the development of a command-information system for the needs of the smallcountry defence system forces as their key component. Project management has a great challenge that is reflected in a complex project for the needs of small countries in the 21st century. Command-information systems are considered multipliers of the capabilities of units and as such have special significance for the defence of small states.
\end{abstract}

Keywords-command-information system, project management, command, control, defence, information system.

\section{INTRODUCTION}

Rapid technological and technical progress in all areas of society has led to the development of new, modern, more murderous and more precise weapons and military equipment. The speed of carrying out combat and other operations affects the increase in the speed of manoeuvring units in the operation zone. The modern command and control system command is, therefore burdened by a large number of data that needs to be processed and transmitted, with the time component allowing for less and less comfort. Therefore, the party that makes decisions about its activities on the basis of timely, reliable and accurate data and information is in the advantage. Timely and accurate information enables the savings of material resources and the rational engagement of the people. Therefore, for the needs of the security forces, it is necessary to develop a command-information system (CIS), which will monitor the modern tendencies of the command and control system.

The CIS development project will meet with many challenges, especially in smaller countries that do not have a leading position in the world. All the current regulations in the systems of defence of Western countries $[1,2]$ agree with all these claims, as well as the current understanding of the theoreticians from the profession $[3,4,5]$.

The small states do not have enough financial resources or other national resources to deploy military forces symmetrically to great powers. In a fashionable complex and often chaotic environment, it

is possible to find different solutions in some situations [6]. There is an increase in the demand and growth of the $\mathrm{C} 2$ systems market (Table 1). However, as a way out of a lack of symmetry small countries can use modern CIS as one of the ways to overcome the problem. It is precisely in this context that project management has a great challenge to develop CIS for the needs of small countries.

TABLE I. C4ISR MARKET VALUE PER YEAR

\begin{tabular}{|c|l|c|}
\hline Year & \multicolumn{1}{|c|}{ Market value $^{\text {a }}$} & $\begin{array}{c}\text { Growth } \\
\text { estimate }\end{array}$ \\
\hline 2016 & USD 90.67 billion & $\sim 10 \%$ \\
\hline 2017 & USD 100.25 billion & $10,5 \%$ \\
\hline$\ldots \ldots$ & $\ldots$ & \multirow{2}{*}{. $3,56 \%$} \\
\cline { 1 - 2 } 2022 & $\sim$ USD 119.39 billion & $-4,4 \%$ \\
\hline 2026 & $\sim$ USD 145.8 billion & \\
\hline
\end{tabular}

a. Research and Markets, Ireland, 2019

For the purposes of understanding the needs of project management in the development and the CIS perspective in the defence system in the second chapter, the IS and CIS sites in the modern security environment will be considered, their importance and necessity. The third chapter will be about reviewing foreign solutions specifically targeted at CIS. In the fourth chapter, a CIS development project will be launched, while in the fifth chapter, the specifics of the CIS development project will be considered, after which the Conclusion will be given.

\section{PLACE OF THE COMMAND-INFORMATION SYSTEM IN THE SYSTEM OF DEFENCE}

The information system (IS) in the defence system serves to work with certain groups of information since its registration, through use to storage. It covers the infrastructure with all the necessary means by means, but also the organization and procedures for the work. By developing technical devices and modernizing the telecommunication network, the basis for wider networking and faster data flow in the system is created. [7]. This will enable the unification of all IS into a single integrated, integrated information system (hereinafter: IIS) that will standardize and facilitate access to information. This is precisely the development of a specific IS so-called. 
command-information system (CIS) that concretizes the application of modern technologies and visibly affects the effects of security forces operations in the contemporary environment [8].

The largest number of ISs serves different planning and administrative needs of the defence system and is used for fewer work stations. Widespread ISs require an appropriate data exchange platform. They are a higher degree of IS development because, in addition to functioning at one workstation, they allow data exchange that can be manual or automatic.

After the establishment of ITS, it is possible for these IS to be unified and connected to each other, thus adjusting to the functioning of the network environment. Such IS is for the needs of human resource agencies, the geographic IS is designed to link geographical and attributive features, the use of spatial information and spatial support during decision-making, health IS, logistics IS, and others [9].

\section{A. The need for a unique information system in the defence system}

Each IS requires a unified, integrated telecommunication system and a computer network for its functioning, which provides the necessary data transfer speed from the highest strategic to the lowest tactical levels. Quality and timeliness of information are requirements that every level of command is trying to provide. Processed and transmitted in real-time, information increases the speed of command, reduces the duration of the decision cycle at all levels, and allows the initiative and supremacy in the armed conflict [10].

The information has always been one of the parameters of power, but in the last decades there has been a sharp advancement in information technology, making it a key factor in gaining battles and wars. Due to the increased importance of information, the issue of information superiority began to be considered. A conflicting party achieves information superiority if the state of imbalance in the information domain is in its favour. Information override can also be described as the ability to deliver the right information to the right users at the right time and form while at the same time preventing the forces of the enemy from doing the same [11]

If the superiority in the information domain becomes absolute, one can speak of the information domination of one party. Nowadays, information domination is reserved for the most technologically advanced states and has caused the application of a new doctrine of warfare, which is information warfare or cyber information warfare $[12,13,14]$. The information war is information warfare closest to the area of command and control. It is made up of all forms of struggle for domination and management of information on a global, state, national level, at the level of the national armed forces and its elements.

In such an environment, the need for a complete organization of information flows, important for defence, is especially evident. Routing information through certain channels and using them requires advanced IS. The ability to fully manage information flows will have a system that in some way, combines all the information used in the defence system. In this sense, the formation of a unique IS, i.e., Integrated information system (IIS) has the importance of the highest - "roof" control mechanism for all information that the defence system uses. The essence of the existence of such a unique system is the unification of all IS into one whole, thus achieving multiple benefits in the management of information.

\section{B. Command-information system in a modern security environment}

After a large number of technical and technological solutions in the development of various ISs for defence through practice, primarily in more developed countries, there was a need for creating ISs that would facilitate the management of units in combat operations. In this way, several ISs are unified under a single platform for the creation of CIS.

The main purpose of the CIS is to support the command and control system in the conduct of combat operations. In order for CIS to have a true significance, command support must be carried out in real or near real-time, whereby the delay of information due to technical and other constraints will not be influenced by decision-making. These conclusions can be presented as follows:

$$
S=f(I s)
$$

$$
\text { Is }=f(\mathrm{CIS})
$$

where:

$\mathrm{S}$ - success in an operation

Is - information superiority

CIS - command-information system

\section{FOREIGN SOLUTIONS IN THE DEVELOPMENT OF CIS}

In order to understand the place and role of CIS in the command and control system, one must first look at the meaning and historical development of the term according to the existing foreign terminology. According to the accepted terminology, from which it originates, different abbreviations are used to indicate different systems. They cannot be easily or with one word translated by existing meanings, which were used in the eastern countries.

In the terminology predominantly derived from the "eastern learning" of the markings of Western command and control systems, primarily involve the functions of military management, and additional resources and procedures necessary for their implementation. The following are the most commonly used concepts of the command and control system. 
$\mathbf{C}^{2}$ (Command and Control) is also referred to as C2 and has a double meaning. On the one hand, it implies the functions of military management, if it is used in theoretical sense or a description of the procedures in the execution of tasks. On the other hand, it implies a system that, in addition to the prescribed procedures, includes both human and material resources for the implementation of missions in a particular environment. Therefore, $\mathrm{C} 2$ can only be a process, as it is most commonly seen, but it can also be the whole system, which becomes especially noticeable in the following system models (C3 and later). As the $\mathrm{C} 2$ system, the initial level of development of command and control systems, as well as the entire group in an everyday speech on this topic (C2 systems ).

$\mathbf{C}^{\mathbf{3}}$ is more often referred to as $\mathbf{C 3}$ (Command, Control and Communications). The next level of development of system $\mathrm{C}$, which implies an integrated telecommunication network for information transmission. It does not clarify the precise level of IS development in qualitative or quantitative terms. It represents the existence of an integrated telecommunication-information platform to which ISs can be upgraded which are connected in the existing network of the defence system. It means the existence of a digital network with modern network services for data transmission, not just the transmission of voice information.

An example of the $\mathbf{C 3}$ system can be identified in the defence system of the Republic of Croatia. In order to support the command and control of the armed forces and the more advanced functioning of the defence system, she included in the strategic plans the construction of a "unique communication and information system", which includes an information infrastructure with implemented basic information exchange services [15]. Such a system corresponds completely to the $\mathbf{C} \mathbf{3}$ model.

$\mathbf{C}^{\mathbf{3}} \mathbf{I}$ is more commonly referred to as $\mathbf{C} \mathbf{3} \mathbf{I}$ (Command, Control, Communications and Intelligence) - It means the use of an existing telecommunications network on which an intelligencereconnaissance system of varying degrees of development is being upgraded, but with the possibility of distributing a higher level of intelligence across the entire network and its use at all levels. It does not imply full implementation of modern CIS.

Although in various forms it was conceived even after the Second World War, concrete activities on the implementation of this standard started in the 1980s. From administrative institutions, first in England in 1985, the C3I Systems Directorate (Directorate for Command, Control, Communication and Intelligence Systems) was established, and similar institutions were established in other heavily Western countries. In 1988, the Assistant Secretary of Defence for the C3I systems was appointed to the United States, who was ranked as the Chief of General Staff of the US Army. This speaks of the importance that was once attached to the development of advanced C2 systems. After that, similar systems were developed in the more technologically advanced countries of the last decade of the $20^{\text {th }}$ century.

Only the meaning of C3I implies the implementation of these characteristics, but it does not specify which level to be developed, which gives the different countries the ability to direct their systems of command and control and gradually achieve the full implementation of the set requirements [16]. An example is Montenegro, which plans to introduce a unique $\mathrm{C} 2$ system by 2025 , with the aim of effectively commanding all units of the army. It will be realized through the project of an integrated marine, air and land surveillance system and the creation of an integrated CIS at all levels of command. To this end, military telecommunication infrastructure is developing, until complete digitalization is achieved, with adequate protection of the transmission pathways to achieve a satisfactory level of C3I capability [17].

The Integrated CIS that is cited does not correspond to the essential meaning of the CIS, because it is related to the next level of development of the $\mathrm{C} 2$ system and is difficult in the basic understanding to bind to the $\mathrm{C} 3 \mathrm{I}$ system that is being explained. "A satisfactory level of C3I" implies partial implementation of intelligence work in the system and reliance on allies in intelligence work.

From the above, it can be concluded that the essence of the model of Montenegro is full implementation of C3, partial technical implementation of intelligence work and some incomplete version of CIS. The model is more than $\mathrm{C} 3$, striving for the next model and can be displayed as C3I.

C4 (Command, Control, Communications and Computers). Compared to $\mathrm{C} 3$, the use of computers, i.e. greater use of computer technology in the use of IS. The development of a decision support system contributed to the implementation of this standard at the end of the 20th century. Increasing processing speed and data transfer speeds enabled the emergence of CIS, which is a basic feature of this model. The emergence of a unique operating picture of the Common Operating Picture and digital visualization has led to a significant improvement in the usefulness of the complete $\mathrm{C} 2$ system.

C4I (C4IS) (Command, Control, Communication, Computer and Intelligence). It was created as the successor to C3I and after the introduction of the CIS into the command and control system. Technologically advanced countries have directly implemented C4I after C3I. It is designed to achieve domination in the information space and the ability to use it as an advantage in a given situation.

C4ISR (Command, Control, Communications, Computers, Intelligence, Surveillance and Reconnaissance) The global fight against terrorism required the examination of a larger, often global environment, and in order to reveal the individual goals of the organization, it had to expand intelligence 
to control elements. Increased use of unmanned aerial vehicles for reconnaissance purposes, as well as other forms of intelligence, the performance of various information operations, increased the amount of data that was to be processed in order to determine the objects of the action. This model was implemented in the first decade of the 21 st century; however, for the needs of the defence system of technologically advanced countries, it is still in use. Different companies are working on the offer of a system of this generation, with CIS constantly improving, in particular "smart" decision support systems that make it easier for decision-makers to make decisions.

Particularly significant in modern, dynamic and non-linear environments, is the examination of a complete battlefield, which requires a more precise visualization, i.e. creating a kind of "image" of the battlefield or area of operation. Such a situation is called Common Operational Picture (COP). This display should be shared between multiple users and provide the information superiority of its own forces. Visualization of the area of operation is a process that allows a commander to more accurately assess the position of his and enemy forces in space, as well as other relevant information within the observation zone of the operation. There must also be a possibility to visually display the planned activities to bring their own forces from the current state to the desired goal. This is the key to achieve information superiority. The largest companies in the military industry offer different types of C2 systems of this type [18]. Northrop Grumman (USA) offers a complete end-toend solution for the C4ISR system. Thales (FRA) offers complete C4ISR for all levels of command and control. The offers stand out the "Common Operating Picture" where companies are trying to integrate as much relevant information as possible in a more understandable and usable form.

Different joint operational or intelligence centres for strategic and integrated levels of $\mathrm{C} 2$ are offered, and this is the "Joint Operations or Joint Intelligence Center". Tactical operations centres "Tactical operations centre" are also offered [19]. All of them in their centre contains the "Decision wall", which essentially represents the hardware performance of "Common operating picture". The current command system in the United Kingdom is C4ISTAR (command, control, communications, computers, intelligence, surveillance, target acquisition and reconnaissance) - similar to that in the United States and France - C4ISR.

C4I2 (Command, Control, Communications, Computers, Intelligence and Interoperability) - C4I model plus interoperability. The expanded C4I model emerged as a need for interagency cooperation within the large defence system itself, but also with the cooperation between different armed forces. In addition to the elements of the $\mathrm{C} 4 \mathrm{I}$ system, a module that implements NATO standards of interoperability is added and is used in situations where there are different multinational operations. The concept separates the "in-house" enclosure of the defence system that implements this model and the "external" open to allies and partners with regulated rights and the allowed level of access for joint mission.

C5I (Command, Control, Communications, Computers, Combat Systems and Intelligence) - C4I model plus combat systems. It is applied to more advanced and more complex components of the armed forces, where combat systems need to be automated. This is especially applied through modern concepts of modern combat marine, submarine, anti-aircraft and anti-aircraft systems where fire automation is required for the task to be performed.

Applying the concept of controlled automated decision-making to the use of fire implies limited permission for the system to start selecting and neutralizing goals. A similar model has been applied in parts of land and airborne operations where complex combat systems exist. In these technologies, Raytheon (USA) has a significant impact that offers a variety of C5I solutions, especially for high-tech, antiaircraft, missile and anti-aircraft requirements [20]. In addition to the above-mentioned models, there are various other combinations that generally contain the aforementioned elements. S5I2 (S4I2 and coordination), S6I2 (S5I2 and co-operation), GCCS (Global Command and Control System) and the like. The essential development of the model is constant due to new technological solutions and a constantly changing operating environment.CIS development project Although in the literature, there are various interpretations of the phases of the project cycle $[21,22,23,24]$, the specifics of this project require a partially altered methodology. The project proposal for the development and implementation of CIS in the defence system, which is covered in this paper, includes the pre-project and project cycle (Fig. 1).

\section{A. Pre-Project Cycle}

The pre-project cycle relies on the functioning of state authorities in a comprehensive analysis and decision-making process. Includes:

- Perceiving the achieved level of development of the C2 system;

- Examining the achieved level of ITS;

- Determining the objectives of the CIS development and implementation project;

- Analyze the needs of the defence system;

- Technological possibilities of the domestic dedicated industry and the possibility of relying on foreign solutions;

- Estimation of costs and time;

- Change of the doctrinal documents;

- The planning, programming, budgeting and execution. 


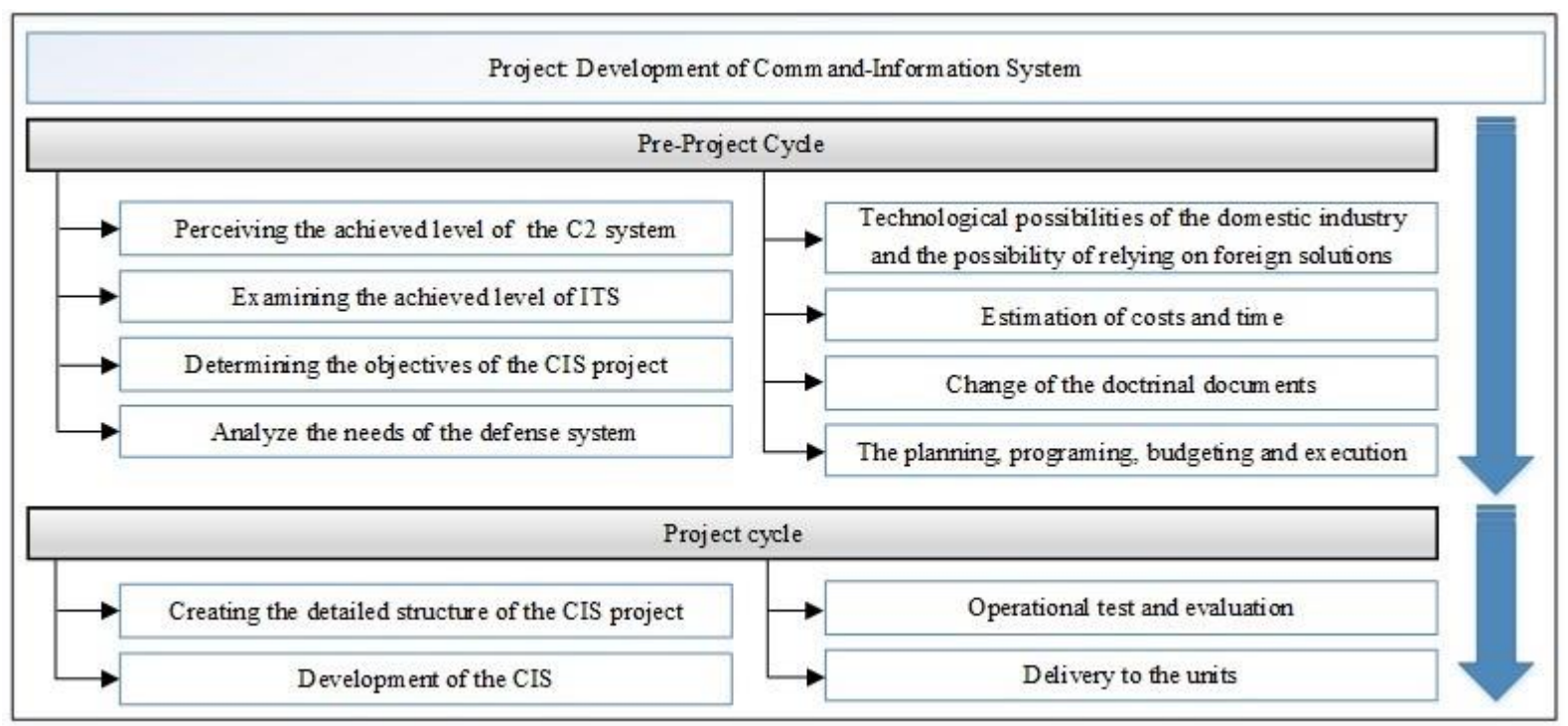

Fig. 1. Model of Project of development of CIS

1) Achieved level of development of the command system

It is considered in relation to theoretically defined and is expressed in part also through the existing environment of the defence system.

2) Achieved level of an integrated telecommunication system (ITS)

In considering the future CIS, it is necessary to start from the current state of the telecommunication system, as a necessary basis for the development of CIS. Modern operating conditions require ITS to enable $\mathrm{C} 2$ in real-time and ensure full integration of capacity levels at $\mathrm{C} 2$ levels for operation needs. The information network forms the core of any modern army organization. It is of particular importance due to the development of IIS and CIS and must be inextricably linked to the telecommunication system (Fig. 2).

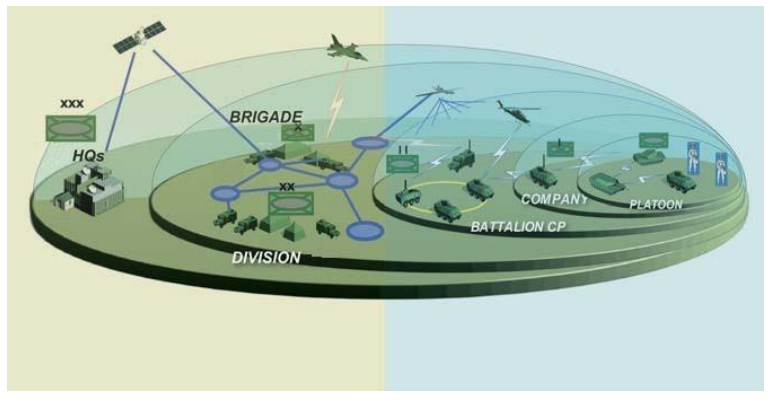

Fig. 2. ITS network C4ISR

The ITS of the defence system of the Republic of Serbia provides real-time data transmission and a satisfactory basis for the establishment of IIS at all levels of command. It represents a modern platform that makes it able to provide the transmission of information for IIS and within it CIS. With its characteristics of the ITS defence system of the Republic of Serbia, the existing system fully meets the requirements of the western $\mathrm{C} 3$ model and represents a platform for possible further upgrading to the $\mathrm{C} 4$, where the defence system of the Republic of Serbia is far ahead of the environment.

3) The objectives of the project of the CIS development and implementation

The ultimate goals of the CIS development and deployment project would need to be to increase the operational capabilities of the security forces achieved through:

- Timely and safe exchange of information at all levels of $\mathrm{C} 2$,

- Assist commanders in assessing the situation and making decisions.

If the goals were to concretize a brigade-level unit (tactical level), they would formulate a specific goal that would, in essence, be to achieve a higher level of operational capacity of the brigade and its subordinate constituencies. This would be realized through concrete goals:

- $\quad$ improving the existing level of $\mathrm{C} 2$;

- individual strengthening of the combat power of units and brigades as a whole;

- information domination in relation to the forces of the enemy;

- the ability to react faster to changes in the environment;

- reducing your own and increasing enemy losses;

- more rational and efficient use of all resources;

- $\quad$ efficient logistics support, etc.;

4) Analysis of the needs of the defence system

The needs of the defence system and the security forces for modern CIS are brought about by the perceived regional and global environment, risks, challenges and threats to the defence system. After looking at the needs in relation to the existing 
solutions, it is necessary to look at the information needs of the users for each IS and the CIS. Any development without the detailed needs of end-users does not lead to a quality and usable solution.

It can be noted that the previously defined needs of the defence system of the Republic of Serbia, as well as each state in the region, indicate the need for the development of some form of CIS tactical level, and as the required capability, the equivalent of the described system C3 or higher is stated. Such needs will be reflected in various official doctrinal and planning documents such as the Strategic Defence Review. Nowadays, any modern level of CIS requires an equivalent with the western system at least the $\mathrm{C} 4$ level, and considering other possibilities of the Republic of Serbia system is not unreachable.

5) Technological possibilities of the domestic military industry

Due to the extreme importance, complexity and sensitivity of the $\mathrm{C} 2$ system, as well as foreign experience, each defence system must independently develop, upgrade and exploit its own CIS. In other words, CIS is not bought but developed for the needs of small countries. Engaging small companies outside the defence system for the CIS project developers do not have a real impetus, as these companies do not have enough systemic knowledge about the object for which it is developing. All entities outside the defence system, in particular foreign corporations, can only have the status of a cooperative contributing to the successful completion of the project and its exploitation in the Serbian Armed Forces.

Although there are foreign companies on the market that sell ready-made C2 systems in the ITS package, reliance entirely on this type of procurement would lead to higher costs, but also to security issues in the defence system.

\section{6) Estimation of costs and time}

All variants and possibilities are taken into consideration to reach the required level of command and control system. Together with the costs, the development time will be calculated, which will vary considerably in certain variants of costs. Usually, the annual fiscal burden is at the expense of a longer period of time. In this regard, the development of the command system can last over ten years, and in this sense it needs to be planned in the long run.

\section{7) Change of the doctrinal documents}

Change of the doctrinal documents is one of the preconditions that CIS would not be an aim and purpose by itself, but it should become a centre of development around which other elements of the defence system would be developed and adapted. For example, the "National Security Strategy of the Republic of Serbia" [25], examining the tendencies of the development of information and communication technologies, warns against possible threats to the systems coming from that direction. It essentially recognizes the importance of a modern information dimension. The "Defence Strategy of the Republic of
Serbia" [26] requires the construction of a system that will provide information in real-time to the command and exchange of information. "Doctrine of the Serbian Armed Forces" recognizes the need for the development of IS and CIS to support command at all levels [27]. Essentially all the doctrinal and planning documents prescribe the need for the development of IIS and CIS, however, in the case of project realization, it would be necessary to introduce guidelines that reflect the situation and requirements of the newspaper.

8) The planning, programming, budgeting and execution of financial plans (PPBI)

PPBI is the final and most important step, especially in small countries with limited budgetary resources. Due to the high cost of CIS, the political commitment and defence system capabilities to fund the project are decisive for further steps [28].

Specific to all these steps is that they all must be fully realized, in order to expect success from the project cycle.

\section{B. The project cycle encompasses:}

- Creating the detailed structure of the CIS project

- Development of the CIS

- Operational test and evaluation

- Delivery to the units

1) Creation of the detailed structure of the CIS project

After looking at previous foreign experiences and domestic possibilities, the CIS model proposal can have the following characteristics:

- Due to the size of the state and the structure of the security forces, the CIS should be developed primarily for tactical use, which involves use at the level of the brigade and lower units.

- Due to different formations at the tactical level, the CIS should first be delivered to the brigades with the highest operating capabilities, and later in the rest. This implies giving priority to units where information technology can most influence the increase in operational capacity and thus the results of combat operations. It's also the best way to see the functioning of the CIS.

The basic structure of the Brigade CIS, according to the proposed model [29], consists of six CIS subsystems. It includes:

- $\quad$ CIS of the brigade HQ;

- $\quad$ CIS of the Intelligence Security Forces;

- $\quad$ CIS of the manoeuvring forces;

- $\quad$ CIS of the Forces for the fire support; 
- $\quad$ CIS of the Air Defence Forces;

- CIS of the Logistics Support Forces;

The most significant and technologically most complex of these subsystems is the brigade HQ CIS. It is intended to connect and integrate all the essential elements of the brigade's forces into a unique network. It should also enable decision-makers to quickly and efficiently respond to a new situation. It implies the development and improvement of the command post (CP) elements with comprehensive technological and applicative support for the work of the brigade HQ.

Although at first sight, it seems too detailed and demanding, the proposed CIS model offers a comprehensive solution that would improve the operational capabilities of the units being equipped with and the defence system as a whole. Considering it in a comparative sense with Western solutions, it fully meets the requirements of the $\mathrm{C} 4 \mathrm{I}$ system and contains the C4ISR elements, whereby with the possible upgrades of the intelligence system, it allows the transition to the above-mentioned level. It is basically the basis for synchronizing and directing the development of all subordinate ISs in the direction of information domination on the battlefield. In addition to the basics in this model are included all subordinate systems that would complete the complete CIS.

2) Development, operational test and evaluation and delivery to the units

Steps in developing and introducing CIS must be adapted to the necessary activities. Particularly in testing and evaluation of the system

\section{SPECIFICITIES OF THE PROJECT OF CIS DEVELOPMENT}

The described project model provides a comprehensive approach to the problem. The proposed model does not clarify the details of the CIS manoeuvring power subsystem, i.e. the need for CIS at the battalion level, but, of course, as with other CIS subsystems, it is in the development phase.

The need for modern CIS is the introduction of a decision support system in the process of military decision-making. The name of the system is subject to consideration. It can also be called $I S$ for support of the process of military decision-making, and it would include specific tools to support concrete decisionmaking. In considering this issue, it must begin from the fact that the initial planning mistake is the most dangerous since in the later it can lead to a whole series of wrong conclusions. Moving through the whole process of making military decisions must be directed to specific ISs that will direct all members of the planning team through the process and in the end facilitate the production of often very extensive documentation. An example of such an IS is TOPFAS, which is designed to analyze the operating environment, planning and support of NATO operations.
The existence of an IS for support of the process of military decision-making would greatly accelerate work and fully standardize the process. Also, very important, this IS would have an integrated decision support system, based on modern methods of decisionmaking theory that would serve as decision support in terms of evaluating courses of action and supporting options throughout the process [30,31]. The IT platform of the network environment for such a system already exists because it does not require special computers and equipment, and the development of this IS, in the beginning, would only require the development of an application part. This allows the development of such a system before the development of the rest of the CIS, which makes it acceptable in conditions of limited resources.

\section{CONCLUSION}

The complexity of CIS does not allow a detailed account of all of its elements in this paper and will be the subject of different research. The development of the IS in the defence system is indispensable in the modern security environment. Its significance for the effective functioning of the defence system is very high.

The importance of CIS as a specific IS gets important in the execution of security forces' operations. It should be noted that the realization of the project of CIS implementation and implementation, despite the high cost of investment, is the most rational and most effective way of increasing the combat power and efficiency of each armed forces both in general and at the level of each individual unit. It represents a large and very complex project for the defence system and its research and development institution. Due to the complexity of the system and the scope of applied technologies, as well as its impact on the armed forces in the organizational, functional and technical-technological domain, the CIS exceeds most of the projects so far realized or is at the top.

After reaching the required level in the development of the CIS, the procedures need to be changed and adapted. The technology must be applied together with the experience of persons in the defence system. We should always keep in mind that all modern armies are in the process of introduction or already have been introduced to CIS, and the development of these systems is of the highest priority. In world developed countries, these systems are treated as multipliers of the impact of their own armed forces, and therefore the special attention is paid to the development and introduction of these systems.

\section{ACKNOWLEDGEMENT}

The work reported on in this paper is a part of the investigation in the research projects VA-DH/2/18-20 supported by the University of Defence in Belgrade. This support is gratefully acknowledged. 


\section{REFERENCES}

[1] Army, U. S. "ADP 3-0 Operations", Washington DC: Headquarters, Department of the Army, 2017, pp. 8.

[2] MoD, U. K. "JDP 0-01 British Defence Doctrine", 2011, pp. 42.

[3] R. Dempsey, and J. M. Chavous, "Commander's intent and concept of operations", Military Review 93.6, 2013, pp. 5866.

[4] E. Blasch, and M. Bélanger, „Agile battle management efficiency for command, control, communications, computers and intelligence (C4I)", Signal Processing, Sensor/Information Fusion, and Target Recognition XXV. Vol. 9842. International Society for Optics and Photonics, 2016.

[5] D. Eisenberg, D. Aldersonet, M. Kitsak, A. Ganin, and I. Linkov, "Network Foundation for Command and Control (C2) Systems: Literature Review", IEEE Access 6, 2018, pp. 68782-68794.

[6] Z. Karavidić, and D. Projović, "Mesto i značaj teorije haosa u komandovanju i rukovođenju operacijama", Vojno delo 69.2, 2017, pp. 164-181.

[7] S. Miletić, T. Kokelj, and M. Manjak, "Metodologija projektovanja integrisane telekomunikacione i računarske mreže komandno--informacionog sistema artiljerijskog diviziona za vatrenu podršku", Vojnotehnički glasnik 60.2 , 2012.

[8] L. Gang, and Y. Su, "Study on Big Data Visualization of Joint Operation Command and Control System", International Conference on Big Data. Springer, Cham, 2018, pp. 372-380.

[9] M. Andrejić, M. Milenkov, and V. Sokolović, "Logistics information system", Vojnotehnički glasnik 58.1, 2010, pp. 33-61.

[10] Doktrina TkIOb Vojske Srbije, Medija centar „Odbrana“, Beograd, 2012, pp. 12.

[11] C. Semerdžiev, „Стратегически информационни системи (C4I) - Субекти на автоматизацията““, Sofia, 2015, pp. 6162.

[12] K. Ramsay, "Information, Uncertainty, and War", Annual Review of Political Science 20, 2017, pp. 505-527.

[13] H. Huang, "A war of (mis) information: The political effects of rumors and rumor rebuttals in an authoritarian country", British Journal of Political Science 47.2, 2017, pp. 283-311.

[14] R. Reddy, B. Burmeister, S. Manamela, U. Mewalal, and U. Kathree, "Simulation architecture for network centric sensors and electronic warfare engagements", 2018.

[15] "Strateški pregled obrane Republike Hrvatske“, Zagreb, 2013 pp. 45.

[16] Ministarstvo odbrane Crne Gore, "Dugorocni plan razvoja odbrane 2016-2025“, Podgorica, 2015, pp. 12.
[17] Ministarstvo odbrane Crne Gore, "Strategijski pregled odbrane Crne Gore", Podgorica, 2013, pp. 46.

[18] Official web site of the Northrop Grumman Company (USA) http://www.northropgrumman.com/Capabilities/C4ISR/Publis hingImages/Infographic-C4ISR.png (09.05.2019.)

[19] Official web site of the Thales Company (FRA) https://www.thalesgroup.com/sites/default/files/database/d7/a sset/document fiche_commander_army_bd.pdf (09.05.2019.)

[20] Official web site of the Raytheon Company (USA): https://www.raytheon.com/news/feature/deconstructingcommand-and-control (09.05.2019.)

[21] Q. Fleming, and J. Koppelman, "Earned value project management. "Project Management Institute, 2016.

[22] A. Walker, "Project management in construction," John Wiley \& Sons, 2015.

[23] R. Turner, "Gower handbook of project management," Routledge, 2016.

[24] E. Verzuh, "The fast forward MBA in project management", John Wiley \& Sons, 2015.

[25] Narodna skupština Republike Srbije, „Strategija nacionalne bezbednosti RS“, Beograd, 2009, pp. 12.

[26] Narodna skupština Republike Srbije, „Strategija odbrane Republike Srbije", Beograd, 2009.

[27] Generalštab Vojske Srbije, Doktrina Vojske Srbije, Beograd, 2010, pp. 17.

[28] S. Raduski, "The planning, programing, budgeting system and its implementation in the Serbian ministry of defence", Journal of Defence Resources Management (JoDRM) 1.1, 2010, pp. 25-32

[29] M. Manjak, and M. Miletić, "Predlog koncepta KIS brigade KoV VS”, Vojnotehnički glasnik 2/2011, Beograd, 2011, pp. $78-93$.

[30] Z. Karavidić, and D. Projović, "A multi-criteria decisionmaking (MCDM) model in the security forces operations based on rough sets", Decision Making: Applications in Management and Engineering 1.1, 2018, pp. 97-120.

[31] D. Bozanic, D. Tešić, and J. Kočić, "Multi-criteria FUCOMFuzzy MABAC model for the selection of location for construction of single-span bailey bridge", Decision Making: Applications in Management and Engineering, 2(1), 2019, pp. 132-146. 